\author{
Original Article
}

\title{
Biological control of incrusting organisms and sediments in Chilean oyster cultures
}

\section{Controle biológico dos organismos incrustáveis e sedimentos em culturas de ostras Chilenas}

\author{
Juan Barile ${ }^{\mathrm{a} *}$ (DD , Gimena Rivasa , Rolando Vega $^{\mathrm{a}, \mathrm{b}}$ (D) and Patricio De los Ríos-Escalante ${ }^{\mathrm{c}, \mathrm{d}}$ (iD \\ aUniversidad Católica de Temuco - UC, Facultad de Recursos Naturales, Departamento de Ciencias Agropecuarias y Acuicolas, Casilla 15-D, \\ Temuco, Chile \\ bUniversidad Católica de Temuco - UC, Núcleo de Producción Alimentaria, Temuco, Araucanía, Chile \\ cUniversidad Católica de Temuco - UC, Departamento de Ciencias Biológicas y Químicas, Facultad de Recursos Naturales, Casilla 15-D, Temuco, \\ Chile \\ dUniversidad Católica de Temuco - UC, Núcleo de Estudios Ambientales, Temuco, Araucanía, Chile
}

\begin{abstract}
The oyster culture has the incrusting organism as problem for production, in this context, it evaluated as biological control against incrusting organism and sediments the introduction of gastropod Tegula atra (Lesson, 1830) in Chilean oysters (Triostrea chilensis Phillippi, 1844) cultures in conditions of starvation presence and absence located in floating cages and bottom cultures. The predation and mechanic effect on $T$. atra grazing generated a decreasing in seven days of $19.8 \%$ and $13.7 \%$ of incrusting organisms in cage culture and bottom sediments by effects of gastropods without starvation respectively. Whereas it had a decrease of $12.6 \%$ and $11.4 \%$ of incrusting organisms in cage culture and bottom sediments by effects of gastropods with starvation respectively. The incrusting organism removed were mainly algae, colonial ascidia, polychaeta, bryozoan and small crustaceans.
\end{abstract}

Keywords: oyster culture, Triostrea chilensis, Tegula atra, biological control.

\begin{abstract}
Resumo
A cultura da ostra tem como problema de produção o organismo incrustante, neste contexto, avaliou como controle biológico contra organismos incrustantes e sedimentos a introdução do gastrópode Tegula atra (Lesson, 1830) em culturas de ostras chilenas (Triostrea chilensis Phillippi, 1844) em condições de presença e ausência de fome, localizadas em gaiolas flutuantes e culturas de fundo. A predação e o efeito mecânico no pastejo de T. atra geraram uma diminuição em sete dias de 19,8\% e 13,7\% dos organismos incrustantes na cultura em gaiola e nos sedimentos de fundo, por efeito de gastrópodes sem fome, respectivamente. Considerando que houve decréscimo de 12,6\% e $11,4 \%$ dos organismos incrustantes na cultura em gaiola e nos sedimentos de fundo pelos efeitos dos gastrópodes com fome respectivamente. Os organismos incrustantes removidos eram principalmente algas, ascídias coloniais, poliquetas, briozoários e pequenos crustáceos.
\end{abstract}

Palavras-chave: cultura de ostras, Triostrea chilensis, Tegula atra, controle biológico.

\section{Introduction}

One of the main limitant factors in oyster culture is the presence of incrusting organism (fouling) and sedimends in cultured species and their respective culture systems (Arakawa, 1990; Guenther et al., 2006; Kishore and Southgate, 2016; Sievers et al., 2017).

The oyster culture has problems due the incrusting organism and sediments depletion and physic-chemical and biological prevention procedures (Sievers et al., 2017), such as natural control in example predators (Lodeiros and García, 2004) that would have interesting projection in shellfish farmings, because these procedures would not generate environmental pollution, that is a disadvantage if it is used physic-chemical methods, and it is a cheap method in comparison to hand extraction (Lodeiros et al., 2018).

It is necessary the control procedures against incrusting organism and sediments that affect the oyster culture in Chile, in this context, the aim of the present study is analyse the capacity of gastropod Tegula atra (Lesson, 1830) as potential biological control considering their herbivore diet (Viviani, 1975), that also it does not has predator or competitor for cultured oysters, and it has

*e-mail: jbarile@uct.cl

Received: April 6, 2020 - Accepted: July 30, 2020

This is an Open Access article distributed under the terms of the Creative Commons Attribution License, which permits unrestricted use, distribution, and reproduction in any medium, provided the original work is properly cited. 
the advantage of wide geographical distribution among rocky shores in Chile and it is easy for collect (Castilla \& Paine, 1987; Osorio \& Reid, 2002; Moreno and Jaramillo, 1983, Moreno et al., 1984; Castilla and Duran, 1985; Castilla et al., 2014).

\section{Material and Methods}

It used adults specimens of $T$. atra, that were utilized in two experiments, in the first it distributed $4 \mathrm{~kg}$ of individuals in 10 suspended hangings from a raft, and similar T. atra quantity in 10 hangings over the substrate. In the second experiment, the T. atra specimens were starved previously during five days. As control, 10 hangings were used in both experiments. The experiment was done in Apiao island close to Chiloe Island ( $42^{\circ} 36^{\prime} \mathrm{S} ; 73^{\circ} 12^{\prime} \mathrm{W}$ ).

For $T$. atra addition in to hangings by raft, was utilized two plastics trays by experiment, that were put at 1,3 and $5 \mathrm{~m}$ depth for generate a T. atra homogeneous distribution in the hangings and around the trays. Tt were located the ten hangings. In each tray were deposited $2 \mathrm{~kg}$ of $T$. atra (191 ind/kg average).

For hangings in the bottom, these were put in parallel, and perpendicular to the coast, and it put $2 \mathrm{~kg}$ of $T$. atra at similar height of the hangings, and $2 \mathrm{~kg}$ in the posterior extreme. Each hanging was individualized and weighted at begin and end of the experiment, without $T$. atra it was used the same procedure for control hangings.

For estimate the differences between, initial and end weight in each hanging, it utilized the pair block test (Sokhal and Rohlf, 1995), and for estimate the effects between treatments ( $T$. atra starved and non-starved), considering the initial total weight the percentage average in incrusting organism and sediments. For this purpose, data were angular transformed for obtain normality and homocedasticity as previous condition for apply one-way ANOVA (Zar, 1999), all statistical analysis were applied with Software SPSS 12.0.

\section{Results}

The hanging weight previous to T. atra introduction was constituted by $59.4 \%$ oysters, $36.4 \%$ of incrusting organisms and $4.2 \%$ of hanging materials (valves, PVC). The main incrusting macroscopic organism were mainly sponges, bryozoan, mytilids, polychaeta, colonial ascidia, tunicates, small crustaceans and algae (Table 1). Between three and four days after experiment beginning the T. atra totality deposited in hangings were displaced to the hangings in a number between $60-80$ individuals by hanging, and they consumed many of the incrusting organism and sediments. At fifth day, T. atra individuals began to detach the hangings, that agree with the incrusting organism and sediments decreasing caused due T. atra scrapper. At seventh day, the T. atra detachment was $82 \%$ as average, and the unique macroscopic incrusting organism were mytilids and the tunicate Pyura chilensis.

It was not observed incrusting organism and sediments removal in control hangings, but, in hangings with T. atra addition, the incrusting organism and sediments removal was significant notorious (Figure 1). The pair block test applied for compare weight loss experimented due T. atra grazing shown that is significant $(\mathrm{p}<0.01)$ in each hanging with $T$. atra starved and non-starved in rafting and bottom culture (Table 2).

The weight loss recorded in first experiment (with T. atra starved) considering the incrusting organism weight and sediments present in hanging was 46\%, whereas in second experiment (with T. atra non-starved) was 33\%. The results of ANOVA revealed significant differences $(\mathrm{p}<0.01)$.

\section{Discusion}

T. atra introduction in oyster hangings also or remove existent flora, it remove significantly important sediment and macroscopic incrusting fauna, the mechanism is difficult for determine, nevertheless, the grazing action would remove small fauna, that would generate remove of potential predators of these small fauna (Margalef, 1998).

Incrusting organism detachment from hangings such as crustacea and polychaeta, was probably by $T$. atra consumed the algal community and sediments that sustain these organisms, similar to the descriptions of Paine (1969), who described the grazing activity of $T$. funebralis on epiphyte diatoms and brown algae (kelps) that are located in intertidal zones. Whereas, probably the sessile fauna removal such as bryozoan, sponges and colonial ascidia would be explained due T. atra grazing or mechanic grazing action. These results would be similar to observations for Chilean intertidal rocky shores (Jara \& Moreno, 1984; Aguilera \& Navarrete, 2011; Castilla et al., 2014).

The minor efectivity observed by $T$. atra located in hangings probably due sediments present in hanging has a disposal of dragged algae due stream action that are entangled to the hangings such as was observed for algae of Ulva genus, that was adhered during the present experiment into hangings, that were grazing by $T$. atra, decreasing proportionally the $T$. atra effectivity incrusting organism and sediment removal from the hangings.

The observed differences obtained in both experiments would suggest that $T$. atra voracity affect the effectivity of them for organism incrusting and sediment removal during a determined time interval, probably starvation generate minor effectivity, and it would generate predation on organism that in optimal physiological conditions are not preferred.

T. atra has a rapidoglose radule that allow macroalgae and microalgae grazing (Reyes et al., 2001), it is mainly a macroalgae herbivore, and ephiphyte such as diatoms and invertebrate scrappers. The Tegula feeding alimentation described it as grazer, that consumpt by action or omission inverebtrates, similar to the results obtained in the present study, and on this basis, T. atra would be omnivorous. Tegula predate on many items, such as macroalgae fragments, foraminifera, dynoflagellates, invertebrate appendixes, sponge spiculae, invertebrate larvae, and parasite sworms (Hidalgo et al., 2013). From 
Table 1. Flora and fauna associated to oyster culture.

\begin{tabular}{|c|c|c|c|}
\hline FAUNA & & FLORA & \\
\hline Porifera: & Porifera non-identified & Chlorophyta: & Enteromorpha Ulva \\
\hline Briozoos & Bugula neritina & Phaeophyta: & Macrocystis \\
\hline \multirow[t]{5}{*}{ Brachiopoda } & Brachiopoda non-identified & Rhodophyta: & Pulysiphonia \\
\hline & Nudibranch & & \\
\hline & Plaxiphora carmichaelis & & \\
\hline & Crucibulum quiriquinae & & \\
\hline & Crepipatela dilatata & & \\
\hline \multirow[t]{6}{*}{ Mollusca: } & Aulacomya ater & & \\
\hline & Semimytilus alghosus & & \\
\hline & Choromytilus algosus & & \\
\hline & Chlamys patagonica & & \\
\hline & Entodesma sp & & \\
\hline & Nereidae & & \\
\hline \multirow[t]{4}{*}{ Annelida } & Terebellidae & & \\
\hline & Polychaeta non identified & & \\
\hline & Cirripedia & & \\
\hline & Amphipoda & & \\
\hline \multirow{4}{*}{ Arthropoda: } & Botaeus truncatus & & \\
\hline & Nauticaris magallanica & & \\
\hline & Halicarcinus planatus & & \\
\hline & Pilomoides perlatus & & \\
\hline Echinodermata: & Loxechinus albus & & \\
\hline \multirow{2}{*}{ Chordata: } & Piura chilensis & & \\
\hline & Colonial ascidia non identified & & \\
\hline
\end{tabular}

Table 2. Incrusting organism and sediments removal from oyster hanging by T. atra grazing effect.

\begin{tabular}{lcccccc}
\hline \multirow{2}{*}{ Sytems } & \multicolumn{5}{c}{ Starved } \\
\cline { 2 - 7 } & $\mathbf{n}$ (hangings) & $\begin{array}{c}\text { Initial weight } \\
(\mathbf{k g})\end{array}$ & $\begin{array}{c}\text { Final weight } \\
(\mathbf{k g})\end{array}$ & $\begin{array}{c}\text { Weight } \\
\text { difference }(\mathbf{k g})\end{array}$ & $\begin{array}{c}\text { Weight } \\
\text { difference (\%) }\end{array}$ & Standard error \\
\hline Raft & 10 & 89.8 & 72.0 & 17.8 & 19.8 & 0.10 \\
Bottom & 10 & 102.3 & 88.3 & 14.0 & 13.7 & 0.11 \\
\hline & \multicolumn{7}{c}{ Non-starved } \\
Raft & 10 & 93.0 & 81.3 & 11.8 & 12.6 & 0.10 \\
Bottom & 10 & 107.8 & 95.5 & 12.3 & 11.4 & 0.13 \\
\hline
\end{tabular}

$\mathrm{n}=$ number of observations for each treatment.

macroalgae, the presence of Chlorophyte (two genus and two non identified), Rhodophyte (one genus) were identified, about Diatoms were identified four genus and 52 species (Perez, 2010). T. atra graze mainly on brown algae such as Macrocystis pirifera and other algae such as Ulva sp. (Chlorophyta), and Mazzaella laminaroides (Rhodophyta) (Pinochet et al., 2018).

In Chile, there are not records of work related with gastropod use as biological controls on incrusting organisms and sediments in oyster hangings and the information related to other countries is scarce. In this context, Arakawa (1990) mentioned that potentially possibilities of biological controls that include selective grazing of some nudibranch on turbellaria, and snail feedings of the Cypraeidae and Lamellaridae families on Botrylloides violaceus Oka, 1927 and B. schlosseri (Pallas, 1766) and other colonial ascidia. Hidu et al. (1981) mentioned the crustacean Cancer irroratus Say, 1817 as efficient biological control in oyster cultures, nevertheless

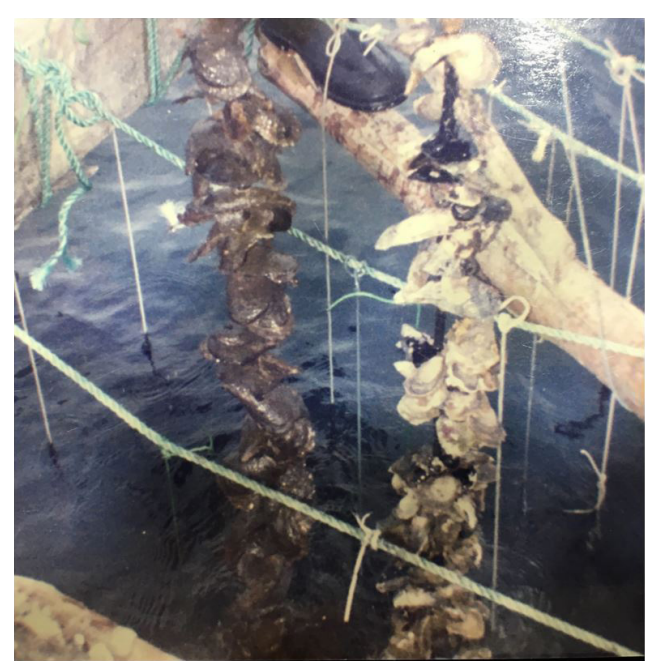

Figure 1. Oyster hangings with T. atra presence and absence for incrusting organisms and sediments removal. 
in comparison to T. atra, this crustacean species in an active predator on juvenile oysters.

The obtained results, and the difficult of found an animal that remove incrusting organisms without damage cultured organism (Maurin and Le Dantec, 1979), would allow that $T$. atra would be an interesting species with potentiality as biological control on incrusting fauna and sediments in oyster cultures and their respective culture systems.

\section{Acknowledgements}

The present study was founded by project MECESUP UCT 0804, also the authors express their gratitude to M.I. and S.M.A for their valuable suggestions for improve the manuscript

\section{References}

AGUILERA, M.A. and NAVARRETE, S.A., 2011. Distribution and activity pattern in an intertidal grazer assemblage: influence of temporal and spatial organization on interspecific associations. Marine Ecology Progress Series, vol. 431, pp. 119136. http://dx.doi.org/10.3354/meps09100.

ARAKAWA, K.Y., 1990. Competitors and fouling organisms in the hanging culture of the pacific oyster, Crassostrea gigas (Thunberg). Marine Behaviour and Physiology, vol. 17, no. 2, pp. 67-94. http://dx.doi.org/10.1080/10236249009378759.

CASTILLA, J.C. and DURAN, L.R., 1985. Human exclusion from the rocky intertidal zone of Central Chile: the effects of Concholepas concholepas (Gastropoda). Oikos, vol. 45, no. 3, pp. 391-399. http://dx.doi.org/10.2307/3565575.

CASTILLA, J.C. and PAINE, R.T., 1987. Predation and community organization on Eastern Pacific, temperate zone, rocky intertidal shores. Revista Chilena de Historia Natural, vol. 60, no. 1, pp. 131-151.

CASTILLA, J.C., MANRIQUEZ, P.H., DELGADO, A., ORTIZ, V., JARA, M.E. and VARAS, M., 2014. Rocky intertidal zonation pattern in Antofagasta, Chile: invasive species and shellfish gathering. PLoS One, vol. 9, no. 10, pp. e110301. http://dx.doi.org/10.1371/ journal.pone.0110301. PMid:25338112.

GUENTHER, J., SOUTHGATE, P.C. and DE NYS, R., 2006. The effect of age and shell size on accumulation of fouling organisms on the Akoya pearl oyster Pinctada fucata (Gould). Aquaculture (Amsterdam, Netherlands), vol. 253, no. 1, pp. 366-373. http://dx.doi.org/10.1016/j.aquaculture.2005.08.003.

HIDALGO, F.J., FIRSTATER, F.N., LOMOVASKY, B.J. and IRIBARNE, O.O., 2013. Grazing effects of the sea urchin Tetrapygus niger and the snail Tegula atra on a rocky shore of central Peru. Journal of the Marine Biological Association of the United Kingdom, vol. 93, no. 8, pp. 2059-2066. http://dx.doi.org/10.1017/S0025315413000994.

HIDU, H., CONARY, C. and CHAPMAN, S.R., 1981. Suspended culture of oysters: biological fouling control. Aquaculture (Amsterdam, Netherlands), vol. 22, pp. 189-192. http://dx.doi. org/10.1016/0044-8486(81)90146-0.

JARA, H.F. and MORENO, C.A., 1984. Herbivory and structure in a midlittorial rocky community: a case in southern Chile. Ecology, vol. 85, no. 1, pp. 28-38. http://dx.doi.org/10.2307/1939455.
KISHORE, P. and SOUTHGATE, P.C., 2016. The effect of different culture methods on the quality of round pearls produced by the black-lip pearl oyster Pinctada margaritifera (Linnaeus, 1758). Aquaculture (Amsterdam, Netherlands), vol. 451, pp. 65-71. http://dx.doi.org/10.1016/j.aquaculture.2015.08.031.

LODEIROS, C., and GARCIA, N., 2004. The use of sea urchins to control fouling during suspended culture of bivalves. Aquaculture (Amsterdam, Netherlands), vol. 231, no. 1-4, pp. 293-298. http://dx.doi.org/10.1016/j.aquaculture.2003.10.022.

LODEIROS, C., RODRÍGUEZ-PESANTES, D., MÁRQUEZ, A., REVILLA, J., CHÁVEZ-VILLALBA, J. and SONNENHOLZNER, S., 2018. Suspended cultivation of the Pacific oyster Crassostrea gigas in the Eastern Tropical Pacific. Aquaculture International, vol. 26, no. 1, pp. 337-347. http://dx.doi.org/10.1007/s10499-017-0217-z.

MARGALEF, R., 1998. Ecología. Barcelona, España: Editorial Omega.

MAURIN, C. and LE DANTEC, J., 1979. The culture of Crassotrea gigas in France. In: R. MANN, ed. Exotic species in mariculture. Cambridge, Massachussetts: MIT Press, pp. 331-354.

MORENO, C.A. and JARAMILLO, E., 1983. The role of grazers in the zonation of intertidal macroalgae of the Chilean coast. Oikos, vol. 41, no. 1, pp. 73-76. http://dx.doi.org/10.2307/3544348.

MORENO, C.A., SUTHERLAND, J.P. and JARA, H.F., 1984. Man as a predator in the intertidal zone of southern Chile. Oikos, vol. 42, no. 2, pp. 155-160. http://dx.doi.org/10.2307/3544787.

OSORIO, C. and REID, D., 2002. Índice bibliográfico sobre biodiversidad acuática de Chile: Bivalvia Mollusca. Ciencia y Tecnología del Mar. CONA, vol. 25, no. 1, pp. 167-175.

PAINE, R.T., 1969. The Pisaster-Tegula interaction: prey patches, predator food preference, and intertidal community structure. Ecology, vol. 50, no. 6, pp. 950-961. http://dx.doi.org/10.2307/1936888.

PÉREZ, L., 2010. Hábitos alimenticios de Tegula eiseni (Jordan, 1936) (Gastropoda: Trochidae) en tres arrecifes rocosos de Baja California sur, México. California Sur: Universidad Autónoma de Baja, 50 p. Tesis para obtener el título de Biólogo Marino.

PINOCHET, R., SOTO, J.C., PALACIOS, M. and OYARZÚN, S., 2018. Selección dietaria de Tegula atra (Lesson, 1830) como una aproximación de preferencia sobre distintas especies de macroalgas en el sur de Chile. Anales del Instituto de la Patagonia, vol. 46, no. 3, pp. 51-60. http://dx.doi.org/10.4067/S0718686X2018000300051.

REYES, Y., CÓRDOVA, C., ROMERO, L. and PAREDES, C., 2001. Marcas radulares producidas por gasterópodos pastoreadores del intermareal rocoso. Revista Peruana de Biología, vol. 8, no. 1, pp. 38-44.

SIEVERS, M., FITRIDGE, I., BUI, S. and DEMPSTER, T., 2017. To treat or not to treat: a quantitative review of the effect of biofouling and control methods in shellfish aquaculture to evaluate the necessity of removal. Biofouling, vol.33, no. 9, pp. 755-767. http:// dx.doi.org/10.1080/08927014.2017.1361937. PMid:28876130.

SOKHAL, R.R. and ROHLF, F.J., 1995. Biometry: the principles and practice of statistics in biological research. New York: W.H. Freeman and Company.

VIVIANI, C., 1975. Las comunidades marinas litorales en el norte grande de Chile. Iquique, Chile: Universidad del Norte, 196 pp. Publicación Ocasional del Laboratorio de Ecología Marina.

ZAR, J.H., 1999. Biostatistical analysis. New Jersey, Upper Saddle River: Prentice Hall Inc. 